$\begin{array}{ll} & \text { Etnográfica } \\ \text { etnográfica } & \text { Revista do Centro em Rede de Investigação em }\end{array}$

Antropologia

vol. 19 (2) | 2015

Vol. $19(2)$

\title{
Masculinity in crisis: effeminate men, loss of manhood, and the nation-state in postsocialist China
}

Masculinidade em crise: homens efeminados, a perda de virilidade e o Estadonação na China pós-socialista

\section{Tiantian Zheng}

\section{(2) OpenEdition}

\section{Journals}

Electronic version

URL: https://journals.openedition.org/etnografica/4026

DOI: 10.4000/etnografica.4026

ISSN: 2182-2891

\section{Publisher}

Centro em Rede de Investigação em Antropologia

\section{Printed version}

Date of publication: 1 June 2015

Number of pages: $347-365$

ISSN: 0873-6561

\section{Electronic reference}

Tiantian Zheng, "Masculinity in crisis: effeminate men, loss of manhood, and the nation-state in postsocialist China", Etnográfica [Online], vol. 19 (2) | 2015, Online since 22 June 2015, connection on 09 February 2022. URL: http://journals.openedition.org/etnografica/4026 ; DOI: https://doi.org/ 10.4000/etnografica.4026

\section{(c) (†) 8}

Etnográfica is licensed under a Creative Commons Attribution-NonCommercial 4.0 International License. 


\section{Masculinity in crisis: effeminate men, loss of manhood, and the nation-state in postsocialist China}

\section{Tiantian Zheng}

The phenomenon of "fake women" sparked indignant discourses chastising it as an epitome of the loss of Chinese manhood and a threat to the nation-state. Experts, counselors, and educators called for "saving boys" through revamping the education system and underscoring gender-difference education in schools and families. Effeminate men have become a scapegoat upon which anxiety over the current social problems such as dissolved marriages is displaced. While a dissolved family is pinpointed as one of the key factors that can lead to a child's effeminacy and gender misrecognition, the media also portrays the lack of manhood not only as a public menace and a threat to the family, but also as a metaphor for passive masculinity and national crisis. Drawing on research of print and electronic media in China from 2010 to 2012, this paper enlightens the inextricably intertwined relationships between a lack of manhood and the strength of the state in the globalizing era of China. It is argued that the crisis of masculinity in effeminate men is considered a peril to the security of the nation because it reflects powerlessness, inferiority, feminized passivity, and social deterioration, reminiscent of the colonial past when China was defeated by the colonizing West and plagued by its image as the "sick man" of East Asia.

KEYWORDS: masculinity, effeminacy, gender roles, state, China.

Masculinidade em crise: homens efeminados, a perda de virilidade e o Estado-nação na China pós-socialista - O fenómeno das "falsas mulheres" gera discursos indignados que o condenam como epítome da perda da virilidade chinesa e uma ameaça ao Estado-nação. Especialistas, conselheiros e educadores apelam ao "salvamento dos rapazes" por meio da renovação do sistema educativo e do reforço da educação sobre as diferenças de género nas escolas e nas famílias. Os homens efeminados tornam-se bodes expiatórios para os quais é transferida a ansiedade a respeito dos problemas sociais atuais, como a dissolução de casamentos. Ao mesmo tempo que aponta a dissolução das famílias como um dos principais fatores que conduzem a que uma criança seja efeminada e não distinga os géneros, a comunicação social retrata a falta de masculinidade como uma ameaça pública e um perigo para a família, e também como metáfora para a masculinidade passiva e a crise nacional. Com base numa investigação realizada em 2010-2012 a partir da imprensa e recursos eletrónicos chineses, o artigo explora a relação inextrincável que interliga uma carência de masculinidade e a força do Estado na era da globalização da China. Argumenta-se que a crise de masculinidade dos homens efeminados é considerada uma ameaça à segurança da nação porque reflete impotência, inferioridade, passividade feminizada e deterioração social, aspetos que remetem para o passado colonial em que a China foi 
derrotada pelo Ocidente colonizador e assolada pela sua imagem de "doente" da Ásia oriental.

PALAVRAS-CHAVE: masculinidade, efeminação, papéis de género, Estado, China.

ZHENG, Tiantian (Tiantian.Zheng@cortland.edu) - State University of New York, USA.

IN THE 2010 NATIONAL HAPPY MEN'S SINGING CONTEST IN CHINA, Liu Zhu - a teenage boy dressed as a woman - participated in the event. ${ }^{1}$ Wearing a rainbow blouse and blue skinny jeans, Liu appeared as a beautiful woman. Due to his strikingly feminine voice and his own stylish long hair, Liu's performance was interrupted three times by the judges who questioned his gender and even threatened him with a strip search. In spite of the setbacks, Liu's performance of the song he had composed conquered the audience and made him famous overnight. Pictures of him as a woman abound in the online media.

This "phenomenon of fake women" (weiniangxianxiang) - effeminate men who look more feminine and alluring than real women - sparked indignant discourses chastising it as an epitome of the loss of Chinese manhood and a threat to the nation-state. ${ }^{2}$ Experts, counselors, and educators called for "saving boys" through revamping the education system and underscoring gender-difference education in schools and families. As I will show in this paper, effeminate men have become a scapegoat upon which anxiety over the current social problems such as dissolved marriages is displaced. While a dissolved family is pinpointed as one of the key factors that can lead to a child's effeminacy and gender misrecognition, the media also portrays the lack of manhood not only as a public menace and a threat to the family, but also as a metaphor for passive masculinity and national crisis.

Studies on man and masculinity have grown ever since the early 1980s. These studies have largely approached masculinity from a Western perspective and attended to peripheral masculinities such as gay or black (see Kimmel 2005; Connell 2001, 2009; Bordo 1999). David Gilmore's (1990) cross-cultural study of various masculinities and Connell's (2001) call for both international and local approaches to the study of masculinity have generated much interest in research on a wide array of masculinities across different cultures and geographic regions (see Louie 2002).

I I would like to acknowledge the helpful comments and advice by Valerio Simoni and Adriana Piscitelli that have improved the quality of the paper.

2 "Fake women" is a role created by Japanese ACG (animation, comics, and games). 
In China studies, little research was conducted to shed light on the contemporary issue of effeminacy or crisis of masculinity and its intrinsic link to the Chinese state. China scholars Xueping Zhong (2000) and Kam Louie (2002) have examined masculinity through in-depth readings and intricate analysis of Chinese films and literary works produced throughout the crucial historical junctures in China. While Xueping Zhong utilizes a feminist psychoanalytic lens that Chinese men feel "besieged" in post-Mao China and attempt to negotiate an image of strong men vis-à-vis women and the state as a part of the effort to create a geopolitically strong Chinese nation, Kam Louie traces the historical changes of the dyad wen/wu (cultural attainment/martial valor) and argues that this dyad is an analytical tool and theoretical construct facilitating the conceptualization of the Chinese masculinities. Also, Brownell and Wasserstrom's (2002) edited book takes an anthropological and historical approach to evoke how femininity and masculinity in China are mutually constructed and have changed over time. As such, previous researchers approached the issue of masculinity through a historical analysis, but to date, no research has been conducted to illuminate the intersection between a crisis of manhood and the postsocialist Chinese state in contemporary globalizing China.

Drawing on my research of online websites, newspaper and magazine articles, TV and electronic media in current China, this paper seeks to fill this lacuna and enlighten the inextricably intertwined relationships between a lack of manhood and the strength of the state in the globalizing era of China. I argue that the crisis of masculinity in effeminate men is considered a peril to the security of the nation because it reflects powerlessness, inferiority, feminized passivity, and social deterioration, reminiscent of the colonial past when China was defeated by the colonizing West and plagued by its image as the "sick man" of East Asia. A multitude of agents and experts are determined to revive and strengthen the nation through building a strong manhood and sharpening proper male gender roles. ${ }^{3}$

3 The question arises as to why this masculine narrative is so popular in China. To understand that we have to look at Chinese history through the last century (T. Zheng 2009). In traditional China, a self-contained culture that paid little attention to outside opinion, there was a masculine ideal that gave prestige to those who were not particularly physically masculine. The mandarins, who represented the highest social ideal in China, were people who worked with their minds rather than their bodies. The symbol of this was long robes that today we would consider feminine clothing and the practice of allowing the fingernails to grow into extraordinary lengths of six inches or more, making the hands unfit for physical labor. This was a powerful symbol of status that rejected physical activity as a defining factor of masculinity. When China, finally in the twentieth century, succumbed to Western aggression after stubbornly clinging to this traditional culture, traditional culture was rejected in favor of what was called a New Culture Movement. The New Culture Movement accepted Western culture and with it, Western definitions of masculinity as sexually potent and aggressive. Implied in this was great shame about China's past and a belief that male feminine nature was the cause of China's troubles in the twentieth century. In spite of Mao's rejection of the "Four Olds" - his attack upon [continues] 
This paper comprises five sections. In the first section, I will historicize masculinities in China and provide a historical context for this paper. In the second section, I will discuss the issue of effeminate men in the media. I will then explore the intersection between masculinity in crisis and the nationstate. In the fourth section, I will analyze the ways in which experts and educators depict the root causes of the lack of manhood in effeminate men. In the fifth section, I will explore the devised solutions to the problem of masculinity in crisis. Finally, I will conclude with insights and illuminations about masculinity, gender roles, rising professionals, and the nation-state in the changing era of postsocialist China.

\section{HISTORICIZING MASCULINITIES IN CHINA}

The meanings of masculinity evolved throughout Chinese history. Before the May Fourth Movement in 1919, the courtesan house was a site that produced an elite masculinity of self-control and cool demeanor. Elite masculinities had to be validated by the courtesans, the arbiters of their masculinity, as worldly, urbane, knowledgeable, sophisticated, and refined (Henriot 2001; Van Gulik 2003). ${ }^{4}$

Concerns about masculine identity at this secure time of "culturalism" (Fitzgerald 1996) have to do with social class. "Culturalism" entailed a universal superiority that Chinese people felt at that time, considering themselves the "Middle Kingdom" - the center of the world and universal superiority. Fairbank (1973: 178) states that China embraced an attitude of being the large ethnocentric universe which "remained quite sure of its cultural superiority even when relatively inferior in military power to fringe elements of its universe."

With the Western intrusion into China, Chinese male insecurity was linked to the perceived decline of China and contributed to the growth of Chinese

[continued] traditional Chinese cultures -, in many ways his standings represented a return to traditional China. Mao represented himself as an all-knowing Emperor whose wisdom brooked no challenge and required complete conformity with his values. Mao's emasculation of men certainly did not follow the traditional lines but nerveless was very effective, even though ironically using the Western ideology of Marxism. The rejection of Marxism in 1978 and the affirmation of the need for a new culture and a new economy led, once again, to a rejection of the traditional view of masculinity as emasculated and feminized and to an affirmation of a macho, Western-style masculinity in its place. The powerful driving force in the post-Mao reaffirmation of a Western style masculinity was a new capitalist economy that emphasized a masculine entrepreneurial spirit.

4 Courtesan houses or public places where courtesans were summoned as professional entertainers formed an integral part of the official and business routine where social relations of officials, literati, artists, and merchants were conducted. Every official entertained his close colleagues - superiors and inferiors and merchants - to conclude or to negotiate deals. An official could ensure his promotion by introducing his superior or an influential politician to a discreetly chosen courtesan, and by the same means, a merchant could obtain a much-needed credit or an important order. 
nationalism. Elite masculinity was attacked because it was identified with the elite cultural tradition (Larson 2002). Nationalism produced a new model of masculinity. For the first time in Chinese history, the sexual ability of Chinese men was not measured internally as a means to establish social class but came to be measured against the outside predators whose military prowess identified them as more sexually potent (see Brownell 2000).

Later on, the Maoist state, with its emphasis on gender equality, attempted to control men's sexuality by suppressing female sexuality (T. Zheng 2009). ${ }^{5}$ Many men remembered this era as an era of male emasculation. In the 1990s, masculinity and marital stability were seen as dependent on women's enjoyment of sex. This radical notion that women should enjoy sex was not out of a concern for the happiness of women, but rather reflected the new competitive capitalist economic model where men proved themselves through entrepreneurial activity. Chinese entrepreneurs, instead of taking offense against the Taiwanese and Japanese businessmen who had taken Chinese mistresses, simply emulated them and took mistresses themselves (Brownell 2000). While young entrepreneurial men recovered their economic and sexual potency, older retired cadres were faced with impotence (Brownell 2000). So devastated was this group that there was an upsurge in the market for tonics to reinvigorate their sexual life. Here, the link between politics, economics, and sexuality is drawn. Men with economic and political power become sexually potent, whereas men who have lost such power feel emasculated by the market reforms.

Entrepreneurial masculinity has been analyzed as inextricably linked to economic and state power (see Connell 2001; Gilmore 1990; Louie 2002; X. Zhong 2000; Brownell 1999; Brownell and Wasserstrom 2002; Chen 2002; Jankowiak 2002; T. Zheng 2006, 2009). Men were judged not by birth status or even education but by their competitive abilities. "Masculinity is related to state power, nationalist ideology, the free market, and the marriage/sex markets. The current situation has unleashed an entrepreneurial masculinity that is apparently proceeding hand in hand with the return of male privilege and female disadvantage" (Brownell 2000: 230). Their subjugation of women represented the recovery of their manhood in postsocialist China.

5 Before liberation, men could gain economic and political power, but in the Maoist society, they were stuck in socialist work units earning the same meager wages as women. The party-state constantly watched over them, stifling their personal ambitions and prohibiting them from speaking their own minds. That led to men's feminization and lack of initiative and creativity. It was believed that the Maoist state's alliance with liberated women stifled men's ability to discover their own strength and led to their feminization. 


\section{"EFFEMINATE MEN" IN THE MEDIA IN POSTSOCIALIST CHINA}

Effeminate men, contrary to the ideal entrepreneurial masculinity in postsocialist China, were given the name "fake women" in the media. The expression "fake women" stemmed from roles created in Japanese animation and comic games, where male actors displayed feminine beauty, and after extensive use of make-up, possibly equaled or at times exceeded feminine beauty (Xia 2010). ${ }^{6}$ News reports portrayed these effeminate men not only appearing in outlandish, ostentatious clothes, but also harboring feminine personalities (Ying 2009; Ju 2009; Ony 2007; Ai 2007; D. Qiao 2005).

Effeminate men became a comic spectacle in the media portrayal. For instance, in a visit to a bar, a reporter categorized the effeminate male clients as ecstatic when you called them "sisters" (Ying 2009). The report called them "female customers" and depicted them as slender "fake women," wearing make-up and women's clothes, speaking in a feminine voice, having undergone cosmetic surgeries, addressing each other as "sisters," and extolling each other as "beautiful" (Ying 2009).

Another newspaper reporter also paid a visit to this kind of a bar and described these men as effeminate "fake women" who either underwent or pursued breast augmentation surgery and "looked more beautiful than ordinary women" (Ai 2007). These men, according to the report, appeared as men during the daytime but as women at night. As the reporter wrote, "MengMeng who had had breast augmentation surgery wore a low-cut dress to show off her cleavage. Xiao Yu was tall, slender, white-skinned, with long and beautiful hair. I would have never believed that he was a man" (Ai 2007). A host of other media reports also focused on how these effeminate men utilized thick facial powder and make-up to make them look like women (D. Qiao 2005).

Effeminate men's feminine personalities were also underscored in addition to their exterior (Lan 2008). It was reported that effeminate men's energy level was lower than "ordinary men" and they rarely liked outdoor activities or body building, probably because "they tried to protect their skin" (Lan 2008). It was said that they only relished singing songs and playing musical instruments, and that they were more emotional than "ordinary men" but they rarely displayed their true emotions (Lan 2008). ${ }^{7}$ Like women, as reports denoted, they also enjoyed eating snacks (Sheng 2009).

One report was written by a female college student who was in dismay that male students in her college liked eating snacks. One summer when she was

6 A Japanese movie, Born for Myself, recounted a story of a man with "gender impediment" who was in love with his boyfriend and after painful struggles, decided to go through a transgendered surgery (Xia 2010). Chongqing counselor Hu Hui told the reporter that this movie had a negative impact on kids in serving as an encouraging movie for them (Xia 2010).

7 This article attributes gender misrecognition to sexual liberation and material desires. 
riding the train home, two male students sat opposite to her, carrying two huge paper bags. They took out a huge amount of snacks from the bags and were eating them for one hour straight without rest. She exclaimed: "How womanly these male students have become! Men nowadays - why are you all turning into women?" (Sheng 2009) Due to their "feminine traits and personalities," media reports stated that it was not surprising that their typical work was as hair stylists and make-up specialists (Ju 2009; Xia 2010), although many were not able to land a job due to their effeminate persona (Zhuang 2008). ${ }^{8}$

Demeaning and mocking commentaries about effeminate men proliferated in the media (Bao 2008; Da 2008; C. Qiao 2005; D. Qiao 2005; Lan 2008). Juxtaposed to "normal men," effeminate men were described as "despicable," "whining," and "swinging hips while walking (yiniuyiniu)" (Bao 2008). A reporter wrote that he was so petrified that his hair stood up when he saw an effeminate man dressed up like a woman, raising his pinky finger, and calling another man "husband" with a coquettish voice (Da 2008).

\section{“MASCULINITY IN CRISIS” AND THE NATIONAL STATE}

While the phenomenon of "fake women" was utilized by special interest groups to sell products (Liu 2012; Xia 2010), worries about the loss of manhood abound in the media. The anti-feminized men discourse represented a serious issue and suggested a crisis of manhood and a crisis of the nation-state. "A China with too many 'fake women' is in peril," as the discourse bellowed (Yue 2012). Feminization of men was castigated as a symptom of social degeneration, ultimately a trope denoting a nation-state in danger because of a dysfunctional Chinese manhood. Experts, educators, and counselors argued that the feminization of males in the past had led to the colonial domination of China.

The lack of manhood was repeatedly linked to the crisis of the nation-state. "The future of our nation is worrisome with the disappearance of manly heroism and masculine spirit," as the discourse lamented (Yue 2012). Authors contended that a harmonious nation should have men who behave like men and women who behave like women, otherwise the nation would cease to be harmonious (Zhang 2012). To save the nation, men's gender-appropriate code of conduct was underscored and reasserted.

The ideal code of conduct for men was defined as fearless, heroic, and militaristic - a vital component of the national spirit. Yuan Luo, General of the Chinese Military Council, published an article that was posted, cited, and expanded throughout the internet (Luo 2010). For China to become the

8 According to a news report about an effeminate man, LvTu, he came out to reporters at a newspaper agency (Zhuang 2008) and pointed out that many male students could not find a job appropriate for them because of their feminine images. 
strongest nation in the world, he contended, men's militaristic, fearless, heroic spirit was imperative. Luo traced the problem back to China's humiliating past when military backwardness caused China to descend into a semi-colonized nation after losing the Opium War and being forced to pay war debts to colonial nations. Military power, according to Luo, reflected national integration and economic power. Now that China's dream to become a strong nation was finally realized, it had to be supported by a strong military (Luo 2010).

The "bad phenomenon" of effeminate men according to Luo was an imminent disaster to the nation-state (guonanlintou), especially when China was still not unified and separatists constituted a threat (Luo 2010). ${ }^{9}$ He lamented that this phenomenon of "yin waxing and yang waning" (ascending female role and descending male role) would destroy national integration and vitality (Luo 2010). "A nation that does not valorize heroes will have no heroes" (Luo 2010).

Luo's indignant diatribe about the phenomenon of feminized men was shared by many (Chong 2010). They articulated men's proper code of conduct: "A man should be like a man. A man needs to be strong and resilient. Men are born to protect and care for women" (Bao 2008; Sheng 2009). "The true meaning of masculinity lies in the spirit of exploring nature, challenging physical limits, and having an unyielding will, rather than sissy clothing and outlook" (Yue 2012). Many people formed anti-“fake-women" groups. A C-block (sissy-block) group appeared at the 2010 Happy Men's Singing Contest, waving a flag that read "Protect pure men. Eliminate fake-women folks" (Chong 2010). An online Anti Fake-Women League with the banner of "Real Chinese Men" was also formed (Chong 2010). ${ }^{10}$

"When the youth are strong, the country is strong. When the youth dominate the earth, the country dominates the earth" (Chong 2010). Invoking the self-strengthening movement at the turn of the twentieth century, the initiator of the Anti Fake-Women League castigated fake women for damaging the image of Chinese men in his article titled "Protect Our Testosterone!" Deploring fake women who had robbed Chinese youth of their testosterone, he asked: "How do youth without testosterone make the country dominate the earth?" (Chong 2010).

Many people joined him in the league, declaring that "At this juncture of the dearth of pure, real men, a man should live like a man" (Chong 2010).

9 Luo defined the future mainstream society as a society with a sound legal system, a masculine and militaristic spirit, and a patriotic and heroic sentiment. Luo stated that without a strong military, the country can never be a strong nation. "A country is not strong until we retrieve the land neighbor countries have plundered from us." Luo reminded people that Communist founding generals sacrificed their lives for this land and this kind of militaristic spirit should be advocated (Luo 2010).

10 The report read that "The initiator was originally silent about the rampant fake-women disaster, but was dismayed at the sight of several fake-women high school students and finally decided to act" (Chong 2010). 
Effeminate men, according to them, suffered psychological perversion and biological regression. Self-defined as "pure men" (chunyemen) and "real men," members claimed that they loved sports and outdoor activities, did Wushu (kungfu), performed sword play, revered real men such as Arnold Schwarzenegger and Alain Delon, and worshipped brotherhood and army troops (Chong 2010). The initiator of the league spent ten thousand yuan on a heavy Tang Dynasty Sword and waved the sword every night imagining himself as a hero rescuing the good and combating the evil. An ex-soldier member went through survival training in the woods with little sustenance for seven days during which time he drank spring water, ate snakes, rats and birds. Members believed that men should be strong and tough. They convened online every night to discuss strategies to fight against the phenomenon of effeminate men (Chong 2010).

\section{"ROOT CAUSES” OF MASCULINITY IN CRISIS}

In the wake of the phenomenon of effeminate men, experts were eager to identify the root causes of effeminate men. According to the experts, family and schools should be regulated and reconfigured to resolve the issue of the crisis of manhood in postsocialist China.

Family and schools were identified as the source of gender misrecognition. The current education system, exam system, and parents' guidance, as the experts contended, were conducive to the phenomenon of effeminate men (Yue 2012; Luo 2010). Yunxiao Sun, editor-in-chief of Youth Studies and board director of the Chinese Family Education Council, published a book entitled Saving Boys (Sun 2009). Sun believed that the education system centered on entrance exams was the most violent killer of manhood (Sun 2009). He stated that boys' testosterone level was 15 times more than girls', which determined the difference between boys and girls upon birth and led to boys' sports-oriented, adventurous, and competitive traits. He argued that because schools planned no outside activities, provided no sports equipment, and prohibited students from running between classrooms, boys, whose biology required extracurricular activities, believed that schools were set up against them. Boys' natural advantage in sports and visual and spatial competence was not recognized. Girls, he stated, could sit still, but boys tended to jump around, which was incompatible with the school system and led to boys' lower grades than girls'. The educational model that lacked game-play and enslaved students with books, repressed boys, and the lack of positive feedback in schools also damaged boys severely (Sun 2009). ${ }^{11}$

11 Sun (2009) pointed out that boys' grades were lower, boys' advantage was not advanced, and boy's development was not guided. 
Sun's criticism of the education system reverberated throughout the media. The stringent education system, as the experts argued, rewarded obedience and docility as the only criteria of a good student, thus robbing children of ingenuity and creativity, extinguishing their personalities, and turning them into domesticated cats (Yue 2012; Lu 2012; Mu 2012). They also affirmed Sun's argument that a lack of outdoor activities and the enclosed school-

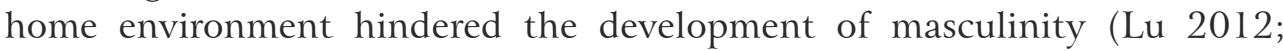
Mu 2012).

The education system was berated for generating a "yin waxing and yang waning" phenomenon, as stated above. In this system, the experts argued, because girls were more meticulous than boys with better self-control and better memorizing skills, their grades tended to be higher than those of boys and allowed them to enter better schools, putting boys at a disadvantage (Lu 2012). In a junior high school, it was said that only three of the 26 leaders were male (Mu 2012). Women also eclipsed men in professional performance and exam grades for government work, as authors noted (Mu 2012). Science majors in universities used to be dominated by males, but are now equally divided between males and females; equal admission of women into medical schools also ended the era of male domination (Mu 2012).

Others such as Shao Yiming, Committee Member of the Chinese Political Association, also pointed out that the ratio of male to female teachers resembled an inverted pyramid. Almost no male teachers could be found in nurseries, and very few taught in elementary schools (Gu 2012). Shao Yiming concluded that the lack of contact with male models led to the lack of "manhood education." Almost exclusively female teachers bred delicate boys who lacked manhood (Lu 2012; Gu 2012; Mu 2012). ${ }^{12}$

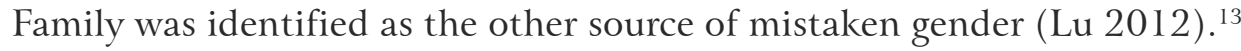
First, parents were blamed on two grounds. They were castigated for making too much demand on boys to study and for fostering an "excessive timid and weak" personality in boys (Yue 2012). They were also chastised for doting on only children, prohibiting boys from climbing trees, climbing mountains, or getting into water, and preventing boys from being independent, adventurous, and taking challenges, thus robbing boys of strong wills and sharp edges (Gu 2012; Mu 2012). ${ }^{14}$ Boys were described as "little emperors," enjoying the love and care of both parents and four grandparents (Lu 2012). They were also depicted as seedlings in a greenhouse that could not withstand

12 The author (Mu 2012) stated that feminized education started in nurseries and it is too late to start saving the boys in junior high.

13 Authors claimed that the criminal was family education (Lu 2012).

14 Author $\mathrm{Mu}$ (2012) pointed out that parents doted on boys and followed the boys everywhere until they screamed in terror at the sight of a roach. This kind of boys, according to the author, could only be tender leaves in green houses and would easily degrade into "fake women." 
any wind or sunshine (Lu 2012; Mu 2012). In an enclosed environment, as authors stated, it was natural for boys to "degrade" into fake-women (Lu 2012; Mu 2012).

Second, fathers were blamed for failing in their role. In his book Saving Boys, Sun (2009) identified the father as the key to nurturing manhood in his son. When fathers were busy advancing their careers, as Sun stated, they deprived the boys of an opportunity to learn to be a man. ${ }^{15}$ Hence Sun argued that the lack of the father's role led to the lack of manhood in boys.

Third, mothers were criticized for being domineering in families. Authors pointed out that in too many families, mothers were dominant and fathers were submissive-like lambs (Lu 2012; Xi 2012). Domineering mothers, according to authors, affected sons in a negative way (Lu 2012). Sun's book intimated that mothers should safeguard fathers' images in front of boys, which would stimulate boys' yearning to assume a man's role (Sun 2009). According to the rhetoric of psychologists in the media, in normal situations, daughters were closer to their fathers and sons were closer to their mothers. A disruption of this normal situation of a bullying mother and a weak father and child abuse by the opposite-sex parent could cause boys to feel fearful of women and embarrassed by their father's humiliation and consequently, develop a mistaken gender recognition (He 2012). ${ }^{16}$

Sociologist Yinhe Li's analysis of the relationship between gender misrecognition and child rearing was cited on many online websites. Li argued that her research demonstrated that the underlying reasons for gender misrecognition were the lack of the fathers' love and child rearing (Li and Wang 1992). First, the missing father's role led to the son's attachment to the mother and distance to the father. As a result, the son self-recognized as a female rather than a male, exhibiting timid and submissive sensibilities and displaying a female posture, female mannerism and female disposition. In addition, their mother-worship either caused their inability to feel attracted to a woman who was seen as far inferior to their mother, or made them revere all women as holy, inaccessible mothers. ${ }^{17}$ Second, parents who raised their boys as girls requiring them to wear girls' clothes and teaching them female-specific work such as knitting and embroidery were also an issue. Third, effeminate looks and a weak physique made some boys want to play with girls and miss their

15 Sun (2009) pointed out that boys needed the discipline and supervision from fathers about how to be a man.

16 It was noted that the boy would yearn for a masculine man and assume a female role in a homosexual relationship. The weak father led to the boy's mistaken gender; and the imperfect mother affected the boy's understanding of the opposite sex - such setbacks led the boy to pursue same sex partners (He 2012).

$17 \mathrm{Li}$ pointed out that many effeminate men could get along with older women but could not like young and beautiful women because they felt in awe before these ( $\mathrm{Li}$ and Wang 1992). 
male-role education. Due to their lack of courage and decisiveness, these boys sought protection from strong men and attachment to strong lovers. ${ }^{18}$ Fourth, abuse by women in childhood led to their disgust towards women ( $\mathrm{Li}$ and Wang 1992).

In consonance with Li's theory, the theory of "abnormal gender misrecognition" stemmed from poor parenting was repeatedly reported throughout the media (Lun 2005; You 2005; Pin 2004; Z. Zhong 2006). Parents' prohibition of opposite sex interactions was also blamed for yielding effeminate boys (Pan 2009; Zi 2010; Zuo 2006; Du 2007; Lin 2012). ${ }^{19}$ Parents were urged to visit a counselor's website and consult with the counselor (Zhuang 2008). Dr. Kong Fanyu, a counselor for the Nanguan Counselor's Center, was cited as an expert who stated that gender education from the age of 2 to 6 was crucial and that it was extremely important and imperative that parents teach kids gender roles. He noted that this problem was difficult to resolve, and that through counseling, he had discovered that this problem was caused by the parents (Zhuang 2008). ${ }^{20}$

According to the psychiatrists, the most crucial time for intervention of gender misrecognition was between $\mathrm{I}$ and 3 , and certainly before the age of 12 . Parents were urged to look for preliminary "symptoms" to "diagnose" whether their children had developed a "gender recognition impediment." These "symptoms" in children were deemed discernible between the ages of 2 and 4 . Symptoms included the child wishing to become the other gender, wanting to wear the opposite gender's clothes, imagining the self as a different gender, aspiring to participate in the opposite sex's entertainment or games, and yearning to become playing partners with the opposite sex. It was noted that boys' feminine behaviors would lead to homosexuality when they grew up. Upon discovery of these issues, parents were advised to work together to solve the problems or seek guidance from counseling centers (Bo 2012).

In a nutshell, disorder is not only denoted a result of gender misrecognition, but also a cause of gender misrecognition and a crisis of manhood.

$18 \mathrm{Li}$ contended that the reason that the youngest son tended to be an effeminate homosexual was because he usually did not like boys' activities that were risky and wild. It was difficult for a loner boy to relate with other boys ( $\mathrm{Li}$ and Wang 1992).

19 Pan (2009) contended that the little resistance of making same-sex friends led kids to transplant their emotional needs to same-sex friends and mistake themselves as homosexuals. According to counselors and health educators, the prohibition of heterosexual contact at an early age made kids fear the opposite sex. Parents' rejection of early heterosexual relationships caused children to seek intimacy and emotional needs through homosexual relationships.

20 Dr. Kong noted that many visitors were parents (Zhuang 2008). 


\section{SOLUTION OF THE CRISIS OF MASCULINITY: REVAMPING THE EDUCATION SYSTEM AND REINFORCING GENDER-DIFFERENCE EDUCATION}

Educators around the country criticized the phenomenon of feminized men and declared that China was facing "a crisis of manhood" and losing a generation of men (Gu 2012; Sun 2009). In the 2012 National People's Congress and the Chinese People's Political Consultative Congress, Ronghua Wang, the head of National People's Representatives and Shanghai Education Development Council, called on the nation to pay attention to the "crisis of manhood" and recommended gender-difference education (yinxingshijiao) (Gu 2012; Sun 2009).

To correct this situation, as educators and media discourse argued, the education system had to change (Yue 2012). Ronghua Wang, board director of Shanghai Education Development and head of Shanghai Social Science Academy, stated that many measures should be taken to solve the "crisis of manhood" (L. Zheng 2012). He contended that the crisis of manhood was inextricably linked to problems in the education system as the exam system and evaluation standards failed to advance boys' advantages and led to their setbacks in study. He argued that a gender-difference education should be carried out nationally and "men's junior high" schools should be established to provide boys with multi-dimensional educational choices (L. Zheng 2012). The lack of coherence in the strategies to fight the feminization of boys is made clear in the decision to create men's junior high schools where boys would be separated from girls during the critical period of their development. As we saw earlier, encouraging heterosexual dating was seen as the solution to gender misrecognition and the crisis of manhood in China.

The new men's junior high schools would establish an agenda to reverse what was perceived as a trend toward the feminization of Chinese men. First, national educators and leaders, following the lead of General Yuan at the Chinese Military Council, argued that a militaristic, patriotic, heroic, and fearless spirit-training should be incorporated in the national education system (Luo 2010; Yue 2012; Lu 2012). ${ }^{21}$

Second, gender-difference education was underscored as urgent and pressing (Sun 2009). In his book Saving Boys, Sun argued that gender difference should be amplified in childhood years and that gender-difference education could combat the phenomenon of feminized boys and gender ambiguity, and create a new generation of real men (Sun 2009).

Sun agreed that boys and girls should be placed in segregated classes and that the education system should apply different evaluation standards to each gender (Sun 2009). Evaluation of boys should emphasize their sporting and adventurous nature, whereas the evaluation of girls should be based on their 
superior memory and language skills. Since sports was in boys' nature, Sun argued, a sports-oriented education would sharpen boys' will and increase their ability to withstand setbacks (Sun 2009).

Third, parents, especially fathers, were called on to assume the prominent role in educating boys (Sun 2009). Parents, as authors argued, should encourage boys to accept challenges in life, provide boys with personality training, and inculcate in boys the meaning of manhood (Gu 2012; Wang 2012; L. Zheng 2012). ${ }^{22}$

Following national educators' call to battle the phenomenon of feminized men, some schools have already started to change. For instance, in Zhengzhou city, the 18th Junior High School stipulated 28 evaluation standards for boys and 20 evaluation standards for girls, requiring boys to be masculine and girls to be demure (Gu 2012).

In Shanghai, East China Normal University signed a contract with Huangpu District Government to turn Shanghai's 8th Junior High School into a “men's junior high school" (Mu 2012; L. Zheng 2012). The headmaster Lu Qisheng clearly stated that the primary purpose of establishing the men's junior high school was to combat "the crisis of manhood" and solve the problem of "yin waxing and yang waning" (Mu 2012, Gu 2012). The goal was to instill in boys a sense of manhood and terminate the phenomenon of feminized men.

In this "men's junior high school," as reported, boys' needs would no longer be ignored, nor would their advantages be undercut as in co-education schools (L. Zheng 2012). As noted by the headmaster, this school would tap into experts' resources and employ a model of boy's education to mould boys' personalities and advance their latent talents (L. Zheng 2012). This personality education was intended to take advantage of boys' perceived logical superiority, and target their disadvantages of weak will and poor planning. The "masculine" curriculum would include boxing, Chinese chess, and male music bands. Schools, as noted by the headmaster, would continuously adjust and perfect teaching techniques to increase boys' self-confidence and make up for their disadvantages (L. Zheng 2012).

Although the Shanghai Huangpu government, the Education Bureau, and East China Normal University supported the establishment of this school and believed that this environment would benefit boys and ensure their growth as real men, some expressed worries that a few qualified, real men trained by the men's junior high schools were not enough to change the entire society's problem of feminized men (L. Zheng 2012; Mu 2012). To completely eliminate the problem of gender misrecognition, authors argued that both schools and parents, especially the father, should indoctrinate boys with male gender roles and girls with female gender roles (Zhang 2012). 


\section{CONCLUSION}

Reactions to the phenomenon of effeminate men in postsocialist China are responsive to the broad cultural changes produced by market reforms. More specifically, it reflects the anxieties about gender, social security, and the nation-state. In this article, I argue that underpinning the discursive debate about effeminate men and a crisis of masculinity is the need to strengthen the nation-state. Indeed, it is believed that to revive and strengthen the nation requires building a strong manhood and sharpening proper male gender roles.

Distinctive gender roles are considered crucial in safeguarding the security of the nation, and are supported and controlled through media discourse. Sexuality is appropriated to control gender in the same way that gender is utilized to control sexuality. The central concern of media discourse is gender behavior, rather than sexual behavior. As illustrated, media articles focus on effeminate men's mistaken gender behaviors and a lack of understanding of gender distinction. The characteristics ascribed to these men as passive and weak are considered deviant. Their mistaken gender identities and misrecognition of gender is not only depicted as creating a crisis of manhood in the nation, but also portrayed as an indicator of poor parenting and a problematic education system. As shown in this paper, educators, psychiatrists, and psychologists have prescribed a myriad of preventive strategies involving parenting and the education system to strengthen socialization and education of proper gender roles and thus combat "the crisis of manhood." As such, gender deviance is governed and controlled in order to prevent and control sexual deviance.

In exploring the root cause of effeminate men and methods to avoid gender misrecognition, the scientific expertise of doctors is sought. The authority of doctors is emphasized when media articles tend to end each story with doctors' comments and appraisals. The kind of power and authority media bestows upon doctors' "scientific" narratives exerts far-reaching impact in the social milieu. This resonates with Foucault's (1978) theorization of governance operated through professional discourse by experts and scientists.

The attitudes of medical professionals reflect the social mores of postsocialist China. As demonstrated in this paper, the rising middle-class medical professionals in contemporary China subscribe to the mainstream sexual morality and advocate cures for and prevention of gender misrecognition. In an effort to advance their profession and procure influence, medical professionals have a vested interest in producing narratives that do not counter cultural norms. This will not only ensure their prestige and influence, but also draw more income to their profession, as parents and effeminate men continuously pay fees to seek their professional, invaluable advice. 


\section{REFERENCES}

AI, Wen, 2007, "Among Taiyuan homosexual group, men have breast augmentation and wear women's clothes" [ tanfang Taiyuan tongxinglianquanshenghuo, nanxinglongxiongchuannvzhuangmiyou], Shanxi News [Shanxi Xinwen Wang], March 27, available at < http://news.sina.com.cn/s/2007-03-27/07231 1502399s.shtml > (last access May 2015).

BAO, Shi, 2008, "Homosexuals: what are you yelling about?" [Tongxinglian - Ni YoushenmoZhideJiaoxiao De], Skyline Community [TianyaShequ], September 24, available at $<$ http://www.tianya.cn/publicforum/content/free/1/1432137.shtml > (last access May 2015).

BO, Si, 2012, "Preventing homosexuality from childhood" [CongxiaoYufangTongxinglian], YanyuanBosi Counseling Center [YanyuanBosiXinliZixunZhongxin], available at < http://www.pkuboss.com/CN/xinlizixun_1001.html > (last access May 2015).

BOrdo, Susan, 1999, The Male Body: A Look at Men in Public and in Private. New York, Farrar, Straus and Giroux.

BROWNELL, Susan, 1999, "Strong women and impotent men: sports, gender, and nationalism in Chinese public culture”, in Mayfair Mei-hui Yang (ed.), Spaces of Their Own. Minneapolis, MN, University of Minnesota Press, 207-231.

BROWNELL, Susan, 2000, "Gender and nationalism in China at the turn of the millennium”, in Tyrene White (ed.), China Briefing 2000: The Continuing Transformation. Armonk, NY, M.E. Sharpe, 195-232.

BROWNELL, Susan, and Jeffrey N. WASSERSTROM, 2002, "Introduction", in S. Brownell and J. N. Wasserstrom (eds.), Chinese Femininities, Chinese Masculinities. Berkeley and Los Angeles, CA, University of California Press, 1-41.

CHEN, Jiali, 2002, "CCTV condom advertisements forced to be changed at the last minute" [Yangshi anquantao guanggao beipo linshi genggai], Chinese News Internet [Zhongxinwang], December 5.

CHONG, Qing, 2010, "Fake-women playing out of bounds? Anti-Fake-Women League in Chongqing calling for real man" [WeiniangDangdaoWanchuwei? Chongqing FanweiniangLianmeng: HuanhuiYangguangHaoErlang], Times Newspaper [ShidaiXinbao], July 5, 11.

CONNELL, Raewin, 2001, "Masculinity politics on a world scale", in S. M. Whitehead and F. J. Barrett (eds.), The Masculinities Reader. Cambridge, Polity Press, 369-374.

CONNELL, Raewin, 2009, Gender: In World Perspective. Cambridge, Polity Press.

DA, Ming, 2008, "Homosexuals, please do not appear in Internet games" [Tongxinglian, QingbuyaoZaiWangluoYouxi Li Chuxian], September 25, available at < http://q.yesky. com/thread-17546824-1-1.html > (last access May 2015).

DU, Xianghong, 2007, "Distinguishing same-sex attachment from same-sex love" [qufenhaotongxingyilianyutongxinglian], Chinese Students [ZhongguoXueshengwang], August 6, available at < http://www.fzsex.fj.cn/409.html > (last access May 2015).

FAIRBANK, John, 1973, Modern China. Cambridge, MA, Harvard University Press.

FITZGerald, John, 1996, Awakening China: Politics, Culture, and Class in the Nationalist Revolution. Stanford, CA, Stanford University Press.

FOUCAUlT, Michel, 1978, History of Sexuality, vol. I. New York, Random House.

GILMORE, David, 1990, Manhood in the Marking: Cultural Concepts of Masculinity. New Haven, Yale University Press. 
GU, Dening, 2012, "A crisis of manhood is reflected by coquettish fake-women league" [QianjiaoBaimei de WeiniangtuanZhesheNanshengWeiji], Around the World Times [HuanqiuShibao], April 10, 4.

HE, Daifu, 2012, "Homosexuals harmed my marriage" [Tongxinglian Haile WodeHunyin], Sex Clinic [XingyixueZhensuo], available at < http://www.xyx120.cn/txlhw\%E5\%90\%8 C\%E6\%80\%A7\%E6\%81\%8B\%E5\%AE\%B3\%E6\%88\%91.htm > (last access May 2015).

HENRIOT, Christian, 2001, Prostitution and Sexuality in Shanghai: A Social History, 18491949. Cambridge, Cambridge University Press.

JANKOWIAK, William, 2002, Proper Men and Proper Women: Parental Affection in the Chinese Family, in S. Brownell and J. N. Wasserstrom (eds.), Chinese Femininities, Chinese Masculinities. Berkeley and Los Angeles, CA, University of California Press, 361-380.

JU, Tong, 2009, "Experiences about homosexuals in Beijing" [Beijing tongxinglianjianwen], September 21.

KIMMEL, Michael, 2005, The Gender of Desire: Essays on Masculinity. Albany, NY, State University of New York Press.

LAN, Yang, 2008, "Investigation on homosexuality" [TongxinglianZhiXiaodiaoyan], Affection for South China [NongqingZhongnan], July 29.

LARSON, W., 2002, "The self loving the self: men and connoisseurship in modern Chinese literature", in S. Brownell and J. N. Wasserstrom (eds.), Chinese Femininities, Chinese Masculinities. Berkeley and Los Angeles, CA, University of California Press, 175-194.

LI, Yinhe, and Xiaobo WANG, 1992, Their World: An X-ray of the Chinese Male Homosexual Group [Tamen de Shijie: zhongguonantongxinglianqunti de toushi]. Beijing, People's Publishing House [RenminChubanshe].

LIN, Ming, 2012, "What reasons cause homosexuals in the low age group?" [shenmoyuanyindaozhitongxingliandilinghua?], Da Ai Wang, January 4, available at < http://www. bamaol.com/html/XLWZ/QGHY/TXLXL/4887220120495937282.shtm > (last access May 2015).

LIU, Peng, 2012, "Fake-women merchandise begin to be popular, sales have been good" [WeiniangShangpinKaishiLiuxing, Shangjia Cheng XiaoliangBucuo], Tianfu Morning Newspaper [TianfuZaobao], January 28, 12.

LOUIE, Kam, 2002, Theorising Chinese Masculinity: Society and Gender in China. Cambridge, MA, Cambridge University Press.

LU, An, 2012, "Can man's junior high school save a crisis of manhood?" [NanziZhongxueJiudeliaoNanshengWeiji Ma], Lu An Xinhua Education [Lu An Xinhua JiaoYu], April 5, available at <http://luanpim.blog.edu.cn/2012/738647.html> (last access May 2015).

LUN, Tan, 2005, "Focus: do female university students regard homosexuality as a vogue?" [ShixianJiaoju: NudaxueshengbaTongxinglianDangchengShishang?], TengxunNuxing, October 1, available at < http://lady.qq.com/a/20051001/000014.htm > (last access May 2015).

LUO, Yuan, 2010, "On the future's mainstream society" [TaolunShenmo Shi WeilaiZhuliuShehui de Wenti], Around the World Times [HuanqiuShibao], December 16, 6.

MU, Yifei, 2012, "Man's junior high school cannot save the crisis of manhood" [NanziZhongguoJiubuliaoNanshengWeiji], Red Net [Hong Wang], April 5, available at < http://hlj.rednet.cn/c/2012/04/05/2572363.htm > (last access May 2015). 
ONY, Shen, 2007, "Same-sex love at college: alternative emotions under pressure" [Gaoxiao TongxingZhi Ai: ChongmanYali de LingleiQinggan], Xinhua Net [Xinhua Wang], March 27, available at < http://edu.qq.com/a/20070327/000066.htm > (last access May 2015). PAN, Haijiao, 2009, "Early love can be changed to homosexuality" [Zaolian ye keyibianchengtongxinglian), 39 Health Community [39 jiankangwangshequ], June 10, available at < www.39. net $>$ (last access May 2015).

PIN, Dao, 2004, "Understanding homosexual relationship" [RenshiTongxingLianqing], March 29, available at < http://www.39. net/mentalworld/hlxl/artz/35689.html > (last access May 2015).

QIAO, Cui, 2005, "Agreeing with homosexuality is an important index for social moral degradation" [Renting tongxinglianshishehuidaodelunsang de zhongyaozhibiao], My Literature City [WodeWenxue Cheng], March 9, available at < http://blog.wenxuecity.com/ myblog/3490/200503/4425.html > (last access May 2015).

QIAO, Dejian, 2005, "Male homosexuals dancing and passionate kissing" [NantongxinglianGewuxiaJiqingYongwen], Western Commercial Newspaper [XibuShangbao], September 26, 15.

SHENG, Qi, 2009, "Running into homosexuals" [OuyuTongxinglian], Zigui Forum [ZiguiLuntan], July 23, available at < http://www.zigui.org/bbs/read.php?tid=28532 > (last access May 2015).

SUN, Yunxiao, 2009, Saving Boys [ZhengjiuNanhai]. Beijing, ZuojiaChubanshe.

VAN GULIK, R.H, 2003, Sexual Life in Ancient China, New York, Brill Academic.

WANG, Pan, 2012, "Man's junior high school cannot block the crisis of manhood" [NanziZhongxueDangbuzhuNanshengWeiji], Dalian Daily [Dalian Ribao], April 5, 13.

$\mathrm{XI}, \mathrm{Si}, 2012$, "How to correct youth homosexuality" [qingchunqiTongxinglianRuheJiaozheng], Chinese Junior High Student Alliance Net [ZhongguoZhongxueshengLianmeng Wang], February 21.

XIA, Jing, 2010, “How are fake-women formed?" [Weiniang Shi ZenyangLiancheng de], Chongqing Ribao [Chongqing Daily], July 2, B7.

YING, Zi, 2009, "Visiting Dalian homosexual group: they are ecstatic when you call them 'sisters'” [JiubaliTanfang Dalian TongxinglianQunti: Beijiaosheng 'Jiejie', TamenGaoxing 'Hui'le], Bandao Morning Newspaper [BandaoChenbao], June 18, B04.

YOU, Haiyang, 2005, “Experts' opinions” [ZhuanjiaGuandian], Labor Newspaper [LaodongBao], September 8,7 .

YUE, Hao, 2012, "A China with too many 'fake-women' is dangerous" ['Weiniang' Taiduo de Zhongguo Shi Weixiande], Eastern Forum [DongfangLuntan], April 10, < http://bbs. eastday.com/viewthread.php?tid=1525432 > (last access May 2015).

ZHANG, Limei, 2012, "Fake-women's incessant performance intensifies gender mistake" [WeiniangtuanShangyanBuduanJiajuXingbiecuowuRenzhi], Guangming Net [Guangming Wang], April 11, < http://news.ifeng.com/opinion/gundong/detail_2012_04/11/13810 505_0.shtml > (last access May 2015).

ZHENG, Lina, 2012, “Shanghai plans to establish man's junior high school to deal with crisis of manhood" [Shanghai NijianNanziZhongxueYingduiNanshengWeiji], Xinhua Net [Xinhua Wang], April 8, available at < http://zt-hzrb.hangzhou.com.cn/system/2012/04/04/011847649.shtml > (last access May 2015).

ZHENG, Tiantian, 2006, "Cool masculinity: male clients' sex consumption and business alliance in urban China's sex industry”, Journal of Contemporary China, 15 (46): 161-182. 
ZHENG, Tiantian, 2009, Red Lights: The Lives of Sex Workers in Postsocialist China. Minneapolis, University of Minnesota Press.

ZHONG, Xueping, 2000, Masculinity Besieged? Issues of Modernity and Male Subjectivity in Chinese Literature of the Late Twentieth Century. Durham, NC, Duke University Press.

ZHONG, Zhengyun, 2006, "Unable to walk out of homosexuality despite bitter struggles" [Kuku ZhengzhangZoubuchuTongxinglian Ganga], West China Metropolitan Newspaper [HuaxiDushiBao], November 18, 26.

ZHUANG, Liming, 2008, "The first homosexual man comes out in Changchun" [Changchun tongxinglianshoucigongkailoumian], East Asian Finance News [DongyaJingmaoXinwen], April 18, 14.

ZI, Xun, 2010, "Good feeling between same-sex intimate friends is not homosexuality" [tongxingmiyouchanshenghaoganbingfeitongxinglian], Shanghai Soul-Park Counseling Center, June 26, available at < http://www.shjgz.net/txl/html/?211.html > (last access May 2015).

ZUO, Feng, 2006, "Attacking early love leads to homosexuality", [mangmufengshazaolianzhitongxinglian], Beijing Technology Newspaper [Beijing Kejibao], March 17, 7. 